\title{
Construction of the Irkutsk-Baikal section of the trans-Baikal railway: state of research
}

\author{
Valery V. Tretyakov ${ }^{1, *}$, Yuri A. Petrushin ${ }^{1}$, Anastasia V. Nekludova ${ }^{1}$, and Elena A. Yakovleva ${ }^{1}$ \\ ${ }^{1}$ Irkutsk State Transport University, 15, Chernyshevsky Str., Irkutsk, Russia
}

\begin{abstract}
The article considers the problems of railway construction in Russia in the 19th and early 20th centuries and finds out the available information on one of the fragments of this grandiose construction in the historical literature. Attention is focused on the construction history of one of the important sections of the Trans-Siberian railway - the Irkutsk-Baikal branch railway, which became the foundation of the Circumbaikal railway. This part of the Great Siberian Railway proved to be a very technically complex construction facility and required significant investments from the state. However, it was not easy to approach to its construction. Its creation was preceded by the work of numerous research teams, selfless labour of designers, engineers, technicians and workers. Thanks to their efforts, our country ultimately managed to establish a continuous rail transportation service and unite the western and eastern parts of Russia, which made it possible to maintain the country's defense capability during the sudden outbreak of the Russian-Japanese War of 1904-1905. The authors specify the main problems that arise when studying the history of the construction and operation of the Irkutsk-Baikal line. They define the range of sources put into circulation by researchers of the designing and construction processes of this road. It is emphasized that the largest number of sources relate to the creation of the line, while the sources which deeply reflect the line operation are few and fragmented.
\end{abstract}

Keywords: Railway construction, Trans-Siberian Railway, Irkutsk-Baikal Railway Line, Baikal Railway Crossing, Trans-Baikal Railway, Great Siberian Railway.

\section{Introduction}

The construction of the Great Siberian Railway is an outstanding achievement of the Russian state. This road provided a reliable communication between the vast territories of Russia and helped to increase the economic potential of the country. Concurrently, it became a significant geopolitical factor. It caused radical changes in all spheres of life of the Siberian society, contributed to the development of modernization processes on the outskirts of the country.

The main chapters of the history of the TransSiberian Railway are generally known. But each of the sections of this railway is unique in its own way, and in each case, engineers had to creatively solve the problems that they faced before the construction. Perhaps the most difficult problem was the connection of the Mid-Siberian and Baikal sections of the Trans-Siberian Railway by continuous track line. Here the foothills of Lake Baikal an area poorly studied in geological and hydrological terms - stood in the way of the construction workers. The designers developed several variants of the line bypassing the Baikal, and each of the projects of the Circumbaikal Railway had its advantages and disadvantages. These discussions continued for a long time. Meanwhile, to solve the problem, a temporary solution to the problem was implemented - the construction of a lake ferry railway crossing. This is the reason why it was originally intended to build a railway linking the Irkutsk station with the Baikal. It wasn't easy to construct this section, but its importance for the TransSiberian railway can hardly be overestimated. The "sticking point", the "bottleneck" of the Trans-Siberian railway - these sharp characteristics are given to this area in the book prepared for Russian readers by C. Wolmar, an English journalist [23].

\section{Problem Statement}

In the 1990s, researchers actively studied the process of constructing the Irkutsk-Baikal railway and its IrkutskBaikal section. The results of this work were presented in several monographs $[18,20]$. At that time, interest in the topic was partly fueled by the desire to recreate the realities of the Trans-Siberian railway construction process on the eve of the upcoming anniversary - the 100th anniversary of the arrival of the first train in Irkutsk. However, in the succeeding years, new publications appeared that address this topic. In addition, new aspects of the study of the topic were identified; new materials were used [5, 9, 19]. Nevertheless, the new knowledge has not yet been analyzed.

* Corresponding author: tretvv@yandex.ru 


\section{Research Questions}

In recent decades, there has been an increase in researchers' interest in the topic. The document collections of the Irkutsk (GAIO, The State Archive of the Irkutsk Region) and the St. Petersburg (RGIA, The Russian State Historical Archive) archives and materials of local and central libraries were studied, which allowed expanding and deepening knowledge about the TransSiberian railway construction process. This resulted in the emergence of new publications and preparation of dissertation studies. Previously unknown stories of the history of the construction of the Irkutsk-Baikal line have been revealed. Many of the hypotheses made earlier have been substantiated. At the same time, the range of issues that attracted the attention of researchers on this topic was clearly defined.

\section{Purpose of the Study}

The aim of this work is to analyze the state of study of the processes of the Irkutsk-Baikal section of the TransSiberian railway. To do this, the following tasks are solved:

- summing up the results of the previous studies;

- defining a range of works emerged in the last two decades that describe the construction of the IrkutskBaikal line at the end of the 19th century;

- defining the source base of the conducted studies, considering the sources previously used;

- determining the prospects for developing the subject.

\section{Research Methods}

The authors used several groups of methods in the study. General theoretical methods of induction and deduction, abstraction and generalization, systematization and interpretation of facts were used as the study basis. In the preparation of the conclusions, the authors used sociological methods of working with empirical data (content analysis, measurement, comparison). But the main method for working with sources and literature was a historical method, and the guiding principles of the study were the principles of objectivity and historicism.

The empirical basis for the study was the data of various nature and meaning, collected in archives and libraries in the course of work.

In interpreting the data and preparing the results of the study, the authors relied on special historical methods. The historical and genetic method made it possible to systematize the data, to establish the main milestones of the process of preparation for the construction of the Irkutsk-Baikal mainline. The application of the historical and comparative method helped to clarify the various states of the process of preparation for the construction of the railway line. At the same time, it helped to establish the specific features of individual states of the process, to determine the meaning of certain solutions in the general case of finding the best way to solve the problems that arose in the design and construction of this line. The use of cause-and-effect analysis allowed the authors to establish links between major and secondary events, which was aimed at building a logically sound sequence of the states of project development processes and their implementation. The application of the historical reconstruction method allowed one to consider the processes of organizing the works of designers, construction workers and railway workers in the unity of subjective and objective aspects. When working with literary sources, the authors relied on retrospective techniques.

\section{Findings}

Previous studies have revealed that the start of construction of the Siberian Railway in 1891 made many problems come to light, and research on the future route line in Eastern Siberia has temporarily receded into the background. But in February 1893 it was decided that the railway would go towards Irkutsk, and it was necessary to accelerate the research. By this time, the projects to bypass Baikal from the north had already been rejected, but the issue of the direction of the route from Irkutsk on the western shore of the lake to the village of Mysovoi (the modern city of Babushkin) on the eastern shore was not solved. Engineers developed different variants of the direction of the Circumbaikal railway through the valleys of the Irkut, Olkha, and Kitoi rivers (Figure 1).

The plan for the construction of this road along the shore of Lake Baikal from the source of the Angara to the village of Kultuk and on to Mysovaya - the project of the line was the shortest in length, but at the same time very costly and complicated in construction - was also considered. It was this option that was eventually implemented. This choice was largely encouraged by the factors of reducing time costs and improving the safety of the railway line: the shortest way was supposed to be arranged on a smooth and geologically solid foundation, which was provided by the rocky shores of the lake. In November 1893, while the decision on the Circumbaikal bypass was not approved, the Committee of Siberian Railways decided to temporarily connect the railway between Irkutsk and the Trans-Baikal ferry crossing. For this purpose, it was planned to specially build icebreakers capable of transporting rail cars, cargo and passengers across the lake. But it was also necessary to construct the railway from Irkutsk to the shore of the Baikal. In February 1894 the Ministry of Railways obtained permission to produce research on the line of Irkutsk - the village of Listvenichnoe, located on the shore to the right of the source of the Angara. This project involved significant construction difficulties, for example, it was necessary to build a float bridge over the Angara in Irkutsk, as the Mid-Siberian Road approached Irkutsk on its left bank. The construction of the line was supposed to begin in 1895. However, more detailed studies have shown significant inconveniences of the Irkutsk-Listvenichnoye direction: the water level in the Angara fluctuated considerably, and during the spring high waters and icefall the float crossing could be interrupted for a month and a half; the construction of a permanent railway bridge was very costly. 


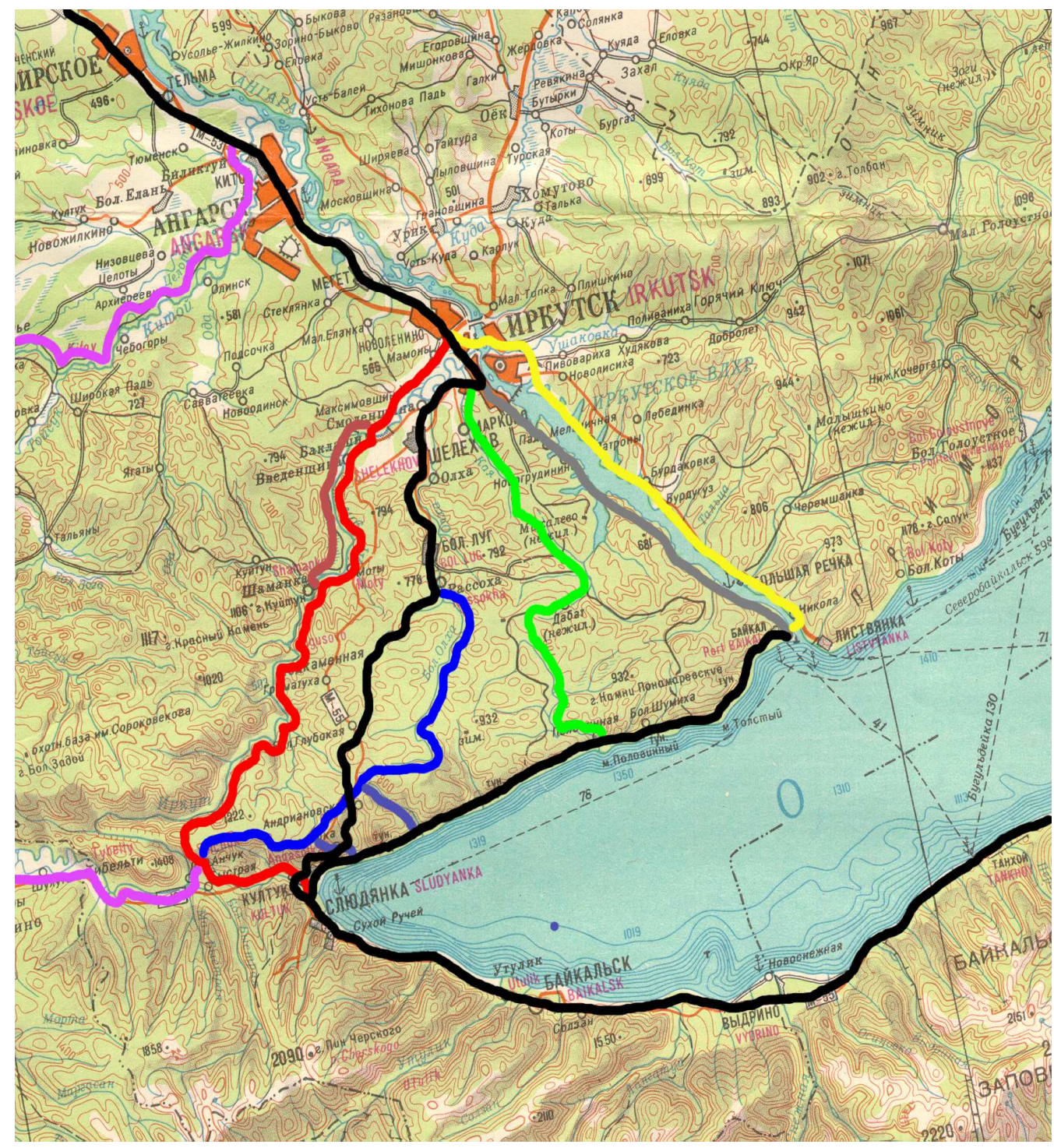

Figure 1. Projects of the Circumbaikal railway. The modern Trans-Siberian railway route is marked in black; the IrkutskListvenichnaya line project - in yellow; the Irkutsk-Baikal line - in gray. (The illustration is from the collection of A.V. Hobta)

It was decided to carry out additional surveys on the left bank of the Angara, which showed that laying a branch there is quite possible. The left-bank project reduced the overall length of the route and did not require the construction of additional bridges, although in comparison with the right-bank version it assumed significant amount of work on the mountain excavation and track construction. At the same time, the project of the Circumbaikal railway construction along the lake shore began to attract special attention, and in this case the Irkutsk-Baikal line would become not a branch, but a section of the Trans-Siberian railway. After numerous discussions, the project was approved and the line was scheduled to be built in 1896. According to the project, it started from the final point of the Mid-Siberian Railway at he Innokentyevskaya station on the left bank of Irkut, crossed it and approached the Irkutsk station on the second verst. The station of Mikhalevo was located on the 26th verst, and the final station of Baikal - on the 64th verst, where the track ended with the wharf exit for the delivery of trains to the icebreaker ferry. To ensure the traffic on the single-track line, passing loops were arranged. In July 1896, the Highest consent for the line construction followed. In October 1898 the laying of rails from Irkutsk to Cape Baranchik on the shore of Baikal was completed, and the preliminary operation of the line was started. In January 1899, a temporary traffic was open on the section. It was put into permanent operation in July 1900 and became part of the officially opened railway [18]. This line was flooded in the 1950s due to the construction of the Irkutsk hydroelectric power plant. Most of it was immersed in the waters of the Irkutsk reservoir. But by that time it was only a siding line, as the main track of the Trans-Siberian railway was laid in a different direction $[2,4,5]$.

The main milestones in the history of the IrkutskBaikal line were found out in the studies of the 1990s. But interest in the subject has not subsequently faded. We have studied the main publications in which it has been touched upon to varying degrees of completeness. The characteristic features of these studies were the expansion of the source base and the addressing to new aspects of the subject. 
The range of archival sources was expanded through deep development of the funds of the Irkutsk and St. Petersburg archives. An important depository is the funds of the Russian State Historical Archive: in 1906, after the construction of the Circumbaikal railway, collections of documents for the construction of this site were taken to St. Petersburg. The main documents are concentrated in the fund No. 1273 (documents of the Committee of the Siberian Railway), but modern researchers turned to the documents of the Fund of the Office for the Construction of the Circumbaikal railway (F. 326), the Fund for Personal Affairs of Communications Engineers (F. 229) and the Fund of Plans and Drawings for the Construction of Railways and Artificial Facilities (F. 350) [8, 9]. This allowed, in particular, finding out the issues of the formation of estimated costs of working expenses, as well as clarifying many details of projects. It was possible to find the documents confirming the existence of plans for the Irkutsk-Baikal line project, which envisaged the construction of a kilometer bridge crossing from the village of Listvennichniy on the right bank of the Angara to Cape Baranchik on the left bank, and then the line was to continue along the shore of the Baikal [9].

The use of the new documents of the Irkutsk Archive made it possible to expand the understanding of the processes of construction work and the emergence of new problems brought by the Trans-Siberian railway: the road disturbed the usual way of life of people, made conflicts escalate. Thus, the Fund of the Office of Construction and Road Units under the Irkutsk Governor-General (F. 31) maintains records of disputes between residents of the areas adjacent to the line under construction and railway workers. For example, residents of the village of Mikhalevo insisted upon crossing the railway tracks for unhindered access to the Angara, as well as asked for a doubling of the bridge spans over the Kurma River (from $3.8 \mathrm{~m}$ to $7.5 \mathrm{~m}$ ), as the narrow span did not allow handling rafts. The documents show that in all cases the administration of the route under construction had to look for compromise solutions [19].

"Journal of the Commission that carried out the survey of the Trans-Baikal railway and the IrkutskBaikal railway line on the occasion of their transfer by the construction department to the operation department" [7], "Album of the as-built drawings for the construction of the Trans-Baikal railway, the Irkutsk-Baikal railway line..." [1], "Report with applications for the construction of a railway line from the city of Irkutsk to Lake Baikal" [16] still remain the base technical documents for the researchers of the subject. But modern researchers began to use them more widely to pay more attention to the technical characteristics of the route. They use longitudinal profiles of the Irkutsk-Baikal line to recreate images of stations and arranged engineering structures [5, 9].

Literature sources have become more widely used in modern research. The historical essay "Siberian Railway in its past and present" based on extracts from official sources [17] remains an important source. For the first time, the book gave a general overview of the process of construction of the Irkutsk-Baikal line, but also provided summary statistics on the total cost of construction of separate sections of the Trans-Siberian railway. This allows comparing the Irkutsk-Baikal line with other sections: for example, if the length of the Tomsk branch was 28.912 rubles, then for the Irkutsk-Baikal branch it was 49.477 rubles. The authors have compiled diagrams of the Trans-Siberian railway performance indicators, which make us think about the importance of the Irkutsk-Baikal road in the transportation of goods and passengers. These data have not been used critically for a long time, but modern studies have shown that they are largely based on project documents and are not always factually accurate [10].

New data were also clarified from the memoirs of the participants of the construction of the Trans-Siberian railway. Thus, from the memoirs of A.V. Liverovskii [11] we became aware of the contents of the minutes of the commission meeting chaired by N.P. Petrov, Deputy Minister of Communications [14], according to which the construction of the Irkutsk-Baikal branch in 1895 was considered as appropriate, but this construction still depended on the development of a common project of the Circumbaikal railway [8]. Another interesting fact was found in the memoirs of A.N. Pushechnikov [15], he appointed the head of construction of the Irkutsk-Baikal branch and the Trans-Baikal railway in the spring of 1895. Preparing for construction and studying the project of the right-bank branch from Irkutsk to the Baikal, it was prepared by engineer G.V. Adrianov. A.N. Pushechnikov decided to discuss it with another prominent engineer and a well-known public figure. As a result of this meeting, the left-bank project of the Irkutsk-Baikal branch was introduced and then implemented [9].

Starting from the 2000s, researchers began to use photographic documents extensively, which allowed them to illustrate the volume of work performed, to help readers forming vivid ideas of the bridges and other engineering structures built on the line, to recreate the paintings of the line in its natural environment [5, 21]. The jubilee editions dedicated to the 100th anniversary of the Circumbaikal railway are particularly noteworthy here [8, 9].

Among the works based on foreign sources, special mention should go to the book by C. Wolmar, the aforenamed British journalist, describing the process of construction of the Trans-Siberian railway in journalistic terms [23]. The merit of the book is the author's brief analysis of the sources from which it turns out that in the review of the history of the Irkutsk-Baikal line, the author rests upon the works of $\mathrm{H}$. Tupper [22] and the book by W. Greener written in 1902 [6], on descriptions of American travelers who were on the Trans-Siberian railway in the early period of its operation [13]. Thus, C. Wolmar notices that $\mathrm{H}$. Tapper emphasizes the special role of M.I. Hilkov, the Minister of Communications, in the choice of direction of the Irkutsk-Baikal line; the conclusion is interesting but it requires confirmation. The question of using books prepared by travelers as sources should be critically and deeply worked out, especially since their authors traveled along the Trans-Siberian railway after the construction of the Circumbaikal railway. 
The article by A.I. Makurin deals with the analysis of the views towards the Trans-Siberian railway of L. Bates, the American engineer on the Trans-Siberian railway, who visited the Trans-Siberian railway in 1908 and published a special book [12]. Although the book by L. Bates [3] does not have a broad historical description, this edition presents the author's general impressions of a trip along the Trans-Baikal railway line, reflects his view of Irkutsk, and presents a set of illustrations, among which there are views of Listvenichny, the Baikal station and other places of the Irkutsk-Baikalskaya line. It may happen that future researchers of this subject will make it possible to use this book more widely as a source.

Finally, one should mention a source such as materials from local newspapers. However, there were few periodicals in those years, and today many of them are in a worn-out state. Carefully flipping through the pages, researchers collect materials on the subject bit by bit. There are also few of them too, since the construction of the Irkutsk-Baikal line was still a small fragment of the grandiose construction of the TransSiberian railway. Nevertheless, in modern research on the subject, materials from the "Irkutsk Gubernskie Vedomosti" and "Eastern review" newspapers are actively used - their collections are relatively complete and include valuable information about the period of the construction of the Irkutsk-Baikalskaya line.

\section{Conclusion}

The construction of the Irkutsk-Baikal line of the TransBaikal railway is one of the unique pages in the history of the Trans-Siberian railway. The general plan for this construction is already well known, but many important details are still to be clarified. For example, further development of the topic may be related to determining the performance indicators of this line, as existing studies often provide target figures. This will require a deep study of the archives. Important aspects of the history of the construction of the railway in the Baikal region can be revealed when assessing the personal relationships between the supervisors of the railway construction. At this point one should study the archival materials of the personal funds of M.I. Khilkov, A.N. Pushechnikov, G.V. Adrianov, and others in detail.

New aspects of the topic can be discovered when working with foreign literature on the history of the Trans-Siberian railway, with the memories of travelers. Although there are few books of this kind, they will make it possible to reveal estimates of the state of the Siberian railway at the turn of the 19th and 20th centuries from foreign observers. Here the researchers will be granted assistance with the materials on the Transsib bibliography, posted on the website Transsib.ru (Transsib.ru. Bibliography).

\section{References}

1. Album of the as-built drawings for the construction of the of the Trans-Baikal railway, the IrkutskBaikal railway line, the railway line to the Chinese border, and the berths of the icebreaker ferry on lake Baikal: 1895-1901 (St. Petersburg, 1902)

2. A.S. Aseeva, A.V. Khobta. Design and exploration work on the new direction of the railway line Irkutsk - Slyudyanka in 1938-1940. J. of the Labor. of Ancient Technol., 1(10), 100-107 (2014)

3. L.W. Bates. The Russian Road to China (Houghton Miffin Comp., Boston; New York, 1910)

4. V. Bryanskij. Second bypass of Baikal (TransSiberian line Irkutsk - Andrianovskaya Sludyanka). Zemlya Irkutskaya, 3(26), 39-43 (2004)

5. A.K. Chertilov. Line Irkutsk - Baikal - the beginning of the railway bypass of the Sacred Sea (Historical and architectural essay). J. of Ancient Technol. Labor., 15(2), 139-157 (2019)

6. W.O. Greener. Greater Russia; the continental empire of the Old world (The Macmillan Co, New York; Macmillan \& Co, Ltd, London, 1903)

7. Journal of the Commission that carried out the survey of the Trans-Baikal railway and the IrkutskBaikal railway line on the occasion of their transfer by the construction Department to the operation Department (Printing of P.I. Makushin \& V.M. Posokhin, Irkutsk, 1901)

8. A.V. Khobta, V.G. Tretyakov. History of the Circum-Baikal Railway 1905-2005 (To the 100th anniversary of the commissioning of the CircumBaikal Railway in permanent operation) (Izdatel A.N. Garashchenko Publ., Irkutsk, 2005)

9. A.V. Khobta. The road to the century: Guidebook album on the Circum-Baikal Railway (Ottisk Publ. House, Irkutsk, 2004)

10. A.V. Khobta History of the construction of the Circum-Baikal railway 1887-1915, Cand. Dissertation thesis (Publ. house of Irkutsk state Univ., Irkutsk, 2005)

11. A.V. Liverovskij. 50 years of railway work (Far Eastern Railway Publ. House, Khabarovsk, 1999)

12. A.I. Makurin. Trans-Siberian Railway in the early 20th century through the eyes of American engineer Lyndon W. Bates. St. Peter. Hist. J., 1, 240-252 (2018)

13. D. Manley (Ed.). The Trans-Siberian railway: $A$ traveler's anthology. (London etc. Century, 1988)

14. N.P. Petrov. Report of the Chairman of the Commission for the study of the construction of the Siberian railway in the area of the Deputy Minister of Railways engineer General-Lieutenant N. Petrova (St. Petersburg, 1896)

15. A.N. Pushechnikov. The case of my rail construction practice. Intellig. of the meet. of railway eng., 25, 431-435 (1913)

16. Report with applications for the construction of a railway line from the city of Irkutsk to Lake Baikal. 1897-1901 (St. Petersburg, 1904)

17. S.V. Sabler, M.V. Sosnovskii. Siberian Railway in its past and present: To the tenth anniversary of the 
Siberian Railway Committee (1893-1903). Historical essay (St. Petersburg, 1903)

18. Transsib.ru. Bibliography. Retrieved from: https://transsib.ru/biblio.htm

19. V.G. Tretyakov (Ed.). The East Siberian railway: a journey through a century (1898-1998) (Publ. house of Irkutsk state Univ., Irkutsk, 1998)

20. V.G. Tretyakov (Ed.). Railway transport in Eastern Siberia from XIX to XXI century, Vol. 1. 1837-1941 (Oblmashinform Publ. house, Irkutsk, 2001)

21. V.G. Tretyakov (Ed). Baikal ferry railway crossing: To the 100th anniversary of construction and operation (Publ. house of Irkutsk state Univ., Irkutsk, 2000)

22. V.G. Tretyakov, V.V. Tretyakov. Irkutsk-Baikal Railway Line. Zemlya Irkutskaya, 3(26), 33-38 (2004)

23. H. Tupper. To the great ocean: Siberia and the Trans-Siberian Railway (Little, Brown, Boston, 1965)

24. C. Wolmar. Trans-Siberian Railway. The history of the creation of the railway skeleton of the empire (Publ. House "Kuchkovo pole", Moscow, 2016) 